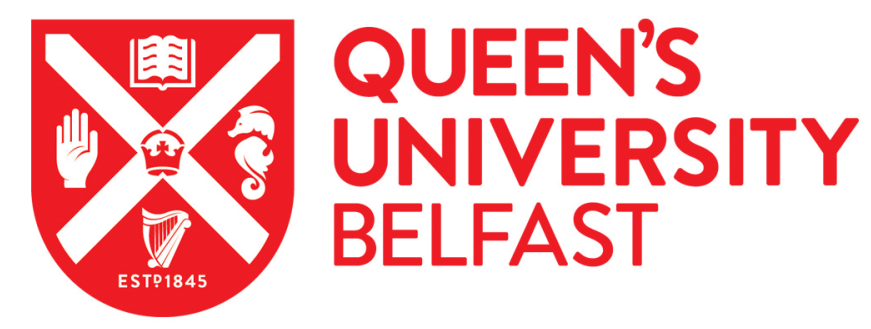

\title{
Growth and nutrient uptake of arbuscular mycorrhizal maize in different depths of soil overlying coal fly ash
}

Bi, Y. L., Li, X. L., Christie, P., Hu, Z. Q., \& Wong, M. H. (2003). Growth and nutrient uptake of arbuscular mycorrhizal maize in different depths of soil overlying coal fly ash. Chemosphere, 50(6), 863-869.

Published in:

Chemosphere

Queen's University Belfast - Research Portal:

Link to publication record in Queen's University Belfast Research Portal

\section{General rights}

Copyright for the publications made accessible via the Queen's University Belfast Research Portal is retained by the author(s) and / or other copyright owners and it is a condition of accessing these publications that users recognise and abide by the legal requirements associated with these rights.

Take down policy

The Research Portal is Queen's institutional repository that provides access to Queen's research output. Every effort has been made to ensure that content in the Research Portal does not infringe any person's rights, or applicable UK laws. If you discover content in the Research Portal that you believe breaches copyright or violates any law, please contact openaccess@qub.ac.uk. 


\title{
CHEMOSPHERE
}

\section{Growth and nutrient uptake of arbuscular mycorrhizal maize in different depths of soil overlying coal fly ash}

\author{
Y.L. Bi ${ }^{\text {a,b }}$, X.L. Li ${ }^{\text {b,* }}$, P. Christie ${ }^{\text {b,c }}$, Z.Q. Hu ${ }^{\text {a }}$, M.H. Wong ${ }^{\text {d }}$ \\ a Department of Resource Development, China University of Mining and Technology, Beijing 100083, China \\ ${ }^{\mathrm{b}}$ Department of Plant Nutrition, China Agricultural University, Beijing 100094, China \\ ${ }^{\mathrm{c}}$ Department of Agricultural and Environmental Science, Queen's University Belfast, Newforge Lane, Belfast BT9 5PX, UK \\ ${ }^{\mathrm{d}}$ College of Natural Resources, Hong Kong Baptist University, Salisbury Road, Kowloon Tong, Hong Kong
}

\begin{abstract}
Application of topsoil over phytotoxic mine wastes is often practised to establish perennial plant communities on minespoil areas. In China, population pressure encourages attempts to remediate such areas by growing arable crop plants, but efforts to establish agricultural crops often fail. We report an outdoor pot experiment that compared the effects of two arbuscular mycorrhizal (AM) fungi, Glomus mosseae (Nicol. and Gerd.) Gerdemann and Trappe and G. versiforme (Karsten) Berch, on the growth and nutrient uptake of maize (Zea mays L.) grown in different depths of soil layer overlying coal fly ash. Colonization by both AM fungi increased plant growth compared with non-mycorrhizal controls, with G. mosseae giving higher yields of maize than G. versiforme at the same depths of soil. Increasing soil depth led to increased plant yields. Mycorrhizal plants absorbed more nutrients than non-mycorrhizal controls, and translocated less $\mathrm{Na}$ to the shoots, perhaps protecting the plants from excessive $\mathrm{Na}$ accumulation. These preliminary results indicate that arbuscular mycorrhizas may make a substantial contribution to successful crop establishment in soils overlying areas of coal fly ash.
\end{abstract}

(C) 2002 Elsevier Science Ltd. All rights reserved.

Keywords: Coal fly ash; Mycorrhiza; Maize; Mine soil; Phytoremediation

\section{Introduction}

The restoration of soils in North American mining areas often involves converting old mine fields to prairie (Cook et al., 1988) or planting prairie species in highly disturbed habitats (Noyd et al., 1995). Removing topsoil from an unmined site adjacent to the mined area and using it to cover the mine spoil is a commonly accepted reclamation practice. The establishment of plant cover on reclamation mine land, however, is only part of the reclamation process. Maintenance of vegetation cover and the creation of a self-sustaining ecosystem after reclamation practices have ceased is of equal importance

\footnotetext{
${ }^{*}$ Corresponding author. Tel.: +86-10-6289-1325; fax: +8610-6289-1016.

E-mail address: lixl@mx.cei.gov.cn (X.L. Li).
}

(Pichtel et al., 1994). Surface (strip) mining, clearing by bulldozer and gullying by erosion (especially in pastures) are likely to expose inoculum-free substrata. Mine spoil is often characterized as having low fertility, low organic matter content, low water-holding capacity, and low soil biological activity, yet it is used as a substitute for topsoil in surface-mine re-vegetation when topsoil is lacking (Reddell and Milnes, 1992). Since re-vegetation objectives may not be met if a suitable soil environment is not provided, amendments such as sewage sludge and arbuscular mycorrhizal (AM) fungi can be added to mine spoil to help create a functional soil (Sabey et al., 1990; Thorne et al., 1998). AM fungi form symbiotic associations with plant roots and have been shown to stimulate re-vegetation of minespoil sites by supplementing the nutrient absorption capacity of the plant root systems, resulting in increased seedling survival and growth (Perry and Amaranthus, 1990). Mycorrhiza can also 
produce qualitative and quantitative shifts in the populations of other soil microbes (Lindermann, 1988). These amendments may also add plant nutrients to the system and help to re-establish biologically driven nutrient cycles that benefit the establishment of re-vegetation species on mine spoil (Hetrick et al., 1994).

Fly ash, a waste by-product of coal combustion, has been noted for its potential use as a soil amendment (Wong, 1995). Its potential benefits include altering soil texture and enhancing water-holding capacity, increasing soil $\mathrm{pH}$ (depending on source), and enhancing soil fertility (Carlson and Adriano, 1993). Application of fly ash to agricultural soils may offer a practical distributed waste recycling alternative to landfill disposal, provided that its positive value for crop growth can be demonstrated and that it does not contaminate the food chain or the environment. The most promising agronomic use for these materials may be to substitute for lime or fertilizers as soil amendments (Schumann and Sumner, 1999).

In China, the most common approach has been the use of coal fly ash as a reclamation material for arable agriculture at the disposal site, usually a collapsed coal mine. The fly ash is placed in the depression formed by subsidence of the exhausted mine and the site is then covered with soil from an adjacent unmined area. Unfortunately, crops planted in such reclamation areas have often grown poorly and the cost of transporting soil to the site can be high. This paper presents the preliminary results of an investigation into the influence of two species of AM fungi on the growth and nutrition of maize planted in disturbed soil overlying coal fly ash. The objectives were to determine whether mycorrhizal colonization could promote the growth of maize and its utilization of the nutrients present in the overlying soil and the fly ash. Different depths of soil and fly ash were included in a pot experiment to determine whether mycorrhizal inoculation would permit a decrease in the depth of the overlying soil without any adverse effects on the growth or nutrition of the maize plants.

\section{Materials and methods}

\subsection{Soil and fly ash}

Calcareous heavy loam soil (Ustarents) was collected from the Pingdingshan coal mining area in Henan Province, China $\left(33^{\circ} 08^{\prime}-34^{\circ} 21^{\prime} \mathrm{N}, 112^{\circ} 12^{\prime}-113^{\circ} 46^{\prime} \mathrm{E}\right)$. Soil was transported to China Mining and Technology University in Beijing where it was passed through a 0.5$\mathrm{cm}$ sieve and large stones and plant roots were removed. The soil was air-dried and contained a total of $0.054 \% \mathrm{P}$, $1.04 \% \mathrm{~K}, 1.33 \% \mathrm{Ca}, 0.80 \% \mathrm{Mg}$, and $62 \mathrm{mg} \mathrm{Zn}, 19 \mathrm{mg}$ $\mathrm{Cu}$, and $27 \mathrm{mg} \mathrm{Mn} \mathrm{kg}^{-1}$. The soil had Olsen $\mathrm{P}$ of about 5 $\mathrm{mg} \mathrm{kg}^{-1}$, and exchangeable $\mathrm{K}$ and $\mathrm{Mg}$ of 190 and 278 $\mathrm{mg} \mathrm{kg}^{-1}$. Soil $\mathrm{pH}$ (soil:water ratio $1: 2.5$ ) was 8.1 prior to sterilization by autoclaving at $121{ }^{\circ} \mathrm{C}$ for $2 \mathrm{~h}$.

Fly ash was also collected from the Xingdian mining area in Pingdingshan City. The fly ash contained $0.044 \%$ total $\mathrm{P}, 0.45 \% \mathrm{~K}, 1.59 \% \mathrm{Ca}, 0.40 \% \mathrm{Mg}, 0.30 \% \mathrm{Na}$, $2.62 \% \mathrm{Fe}$, and $47 \mathrm{mg} \mathrm{Zn}, 84 \mathrm{mg} \mathrm{Mn}$, and $96 \mathrm{mg} \mathrm{Cu} \mathrm{kg}^{-1}$. The fly ash contained $42 \mathrm{mg}$ Olsen $\mathrm{P} \mathrm{kg}^{-1}$ and 29 and 64 mg exchangeable $\mathrm{K}$ and $\mathrm{Mg} \mathrm{kg}^{-1}$. The $\mathrm{pH}$ was 9.4 (ash:water ratio 1:2.5).

\subsection{The pot experiment}

The pots used were $20-\mathrm{cm}$ diameter plastic pots. Fly ash was placed in the bottom of the pots to give depths of 5,7 , and $10 \mathrm{~cm}$, with corresponding weights of fly ash of 800,1350 , and $2050 \mathrm{~g}$. These were covered with aliquots of sterilized (autoclaved) soil of 2550, 2000 and $1300 \mathrm{~g}$ respectively, giving soil depths of 10,8 and $5 \mathrm{~cm}$, and a total depth of growth substrate of $15 \mathrm{~cm}$, corresponding to a total weight of substrate of $3350 \mathrm{~g}$ per pot. Mycorrhizal treatments received $20 \mathrm{~g}$ of fresh inoculum (either G. mosseae or G. versiforme), while non-mycorrhizal plants received $20 \mathrm{~g}$ of sterilized mixed inoculum of both AM fungi together with $10 \mathrm{ml}$ of an aqueous filtrate $(0.25 \mu \mathrm{m}$ pore size $)$ of unsterilized soil $(1: 2 \mathrm{w} / \mathrm{v}$ soil:water) to provide a similar microflora except for the absence of viable mycorrhizal fungi. Inoculum, consisting of fragments of colonized maize roots from pot cultures in sterilized sand, was mixed thoroughly with the growth substrate in each pot. The two AM fungi were provided by Professor H.G. Wang of the Institute of Soils and Fertilizers, Chinese Academy of Agricultural Sciences.

Maize seeds (Zea mays L. cv. Xiedan 969) were pregerminated and two seedlings were transplanted into the soil layer in each pot. All treatments received basal applications of $300 \mathrm{mg} \mathrm{N}$ (as $\mathrm{NH}_{4} \mathrm{NO}_{3}$ ) and $300 \mathrm{mg} \mathrm{K}$ (as $\left.\mathrm{K}_{2} \mathrm{SO}_{4}\right) \mathrm{kg}^{-1}$. Soil moisture was regularly maintained at $70-90 \%$ of water-holding capacity by weight. After 1 month, $20 \mathrm{mg} \mathrm{P} \mathrm{kg}{ }^{-1}$ was added to the soil as $\mathrm{KH}_{2} \mathrm{PO}_{4}$. There were three mycorrhiza treatments (non-mycorrhizal and two AM fungi), and two of these treatments (non-mycorrhizal and G. mosseae inoculum) were combined with all three substrates. Plants inoculated with G. versiforme were grown on two of the substrates, $10 \mathrm{~cm}$ soil $/ 5 \mathrm{~cm}$ fly ash and $8 \mathrm{~cm}$ soil $/ 7 \mathrm{~cm}$ fly ash. Thus there were eight treatments and five replicates giving a total of 40 pots in a randomised block.

The plants grew outdoors in Haidian District, Beijing from 25 May until 20 July 2000. The weather conditions were usually dry, but the pots were protected during rain events by a transparent plastic roof. The shoots and roots were harvested after growth for 8 weeks. The roots were carefully washed free of soil with tap water and were cut into segments about $1 \mathrm{~cm}$ in length. A 1 -g 
subsample of fresh roots was randomly selected from each pot and the roots were cleared overnight in $10 \% \mathrm{v} / \mathrm{v}$ $\mathrm{KOH}$, acidified for $1 \mathrm{~h}$ in $1 \% \mathrm{v} / \mathrm{v} \mathrm{HCl}$, stained overnight with $0.05 \% \mathrm{w} / \mathrm{v}$ Trypan blue and de-stained with acidic glycerol. The proportion of root length infected was determined by examining the stained roots under a compound microscope using the gridline intersect method (Phillips and Hayman, 1970). The dry weights of bulk roots and shoots were determined after oven drying at $70{ }^{\circ} \mathrm{C}$ for $48 \mathrm{~h}$. Subsamples of oven-dried roots and shoots were milled to pass through a $0.5-\mathrm{mm}$ sieve and dry ashed at $500{ }^{\circ} \mathrm{C}$ for multi-element analysis by inductively coupled plasma-atomic emission spectroscopy (ICP-AES).

Data were subjected to analysis of variance (ANOVA) using the GENSTAT package (GENSTAT Committee, 1994). Pairs of means were compared by calculation of least significant difference (LSD) at the 5\% level.

\section{Results}

\subsection{Arbuscular mycorrhiza colonization}

No AM fungal colonization of maize was observed in root subsamples from any of the non-mycorrhizal treatments. The mean proportion of total root length colonized in the mycorrhizal treatments ranged from $39 \%$ to $54 \%$ (Table 1 ), but there was no significant difference between the two fungal species or the different soil/fly ash depth combinations.

\subsection{Maize shoot and root yields}

Non-mycorrhizal plants had the lowest shoot and root yields, and their yields were unaffected by the depths of soil and fly ash (Table 2). Highest shoot and

Table 1

Mean proportion of total root length colonized in the mycorrhizal treatments

\begin{tabular}{llcl}
\hline $\begin{array}{l}\text { AM } \\
\text { fungus }\end{array}$ & $\begin{array}{l}\text { Soil depth } \\
(\mathrm{cm})\end{array}$ & $\begin{array}{l}\text { Fly ash depth } \\
(\mathrm{cm})\end{array}$ & $\begin{array}{l}\text { Proportion of } \\
\text { root length col- } \\
\text { onized }(\%)\end{array}$ \\
\hline $\begin{array}{l}\text { Glomus } \\
\text { mosseae }\end{array}$ & 10 & 5 & $39.4 \mathrm{a}^{\mathrm{a}}$ \\
& 5 & 7 & $50.7 \mathrm{a}$ \\
Glomus & 10 & 10 & $44.0 \mathrm{a}$ \\
versiforme & 8 & 5 & $45.5 \mathrm{a}$ \\
Significance & of differences due to: & $54.0 \mathrm{a}$ \\
& AM fungus & \\
& Substrate & $\mathrm{NS}$ \\
& Interaction & $\mathrm{NS}$ \\
& & $\mathrm{NS}$
\end{tabular}

\footnotetext{
${ }^{a}$ Means followed by the same letter are not significantly different by LSD at the $5 \%$ level.

${ }^{\mathrm{b}}$ By analysis of variance; NS, not significant.
}

Table 2

Mean shoot, root, and total dry matter yields of mycorrhizal and non-mycorrhizal maize grown in various depths of soil and coal fly ash

\begin{tabular}{|c|c|c|c|c|c|}
\hline $\begin{array}{l}\mathrm{AM} \\
\text { fungus }\end{array}$ & $\begin{array}{l}\text { Soil } \\
\text { depth } \\
(\mathrm{cm})\end{array}$ & $\begin{array}{l}\text { Shoots } \\
\left(\mathrm{g} \mathrm{pot}^{-1}\right)\end{array}$ & $\begin{array}{l}\text { Roots } \\
\left(\text { g pot }^{-1}\right)\end{array}$ & $\begin{array}{l}\text { Total } \\
\left(\mathrm{g} \mathrm{pot}^{-1}\right)\end{array}$ & $\begin{array}{l}\text { Root/ } \\
\text { Shoot } \\
\text { (ratio) }\end{array}$ \\
\hline \multirow{3}{*}{$\begin{array}{l}\text { Non- } \\
\text { mycorrhizal }\end{array}$} & 10 & $2.25 \mathrm{c}^{\mathrm{a}}$ & $1.10 \mathrm{de}$ & $3.27 \mathrm{c}$ & 0.49 \\
\hline & 8 & $2.11 \mathrm{c}$ & $0.85 \mathrm{e}$ & $2.96 \mathrm{c}$ & 0.40 \\
\hline & 5 & $2.17 \mathrm{c}$ & $1.06 \mathrm{de}$ & $3.35 \mathrm{c}$ & 0.49 \\
\hline Glomus & 10 & $9.01 \mathrm{a}$ & $3.24 \mathrm{a}$ & $12.25 \mathrm{a}$ & 0.36 \\
\hline \multirow{2}{*}{ mosseae } & 8 & $7.44 \mathrm{ab}$ & $2.78 \mathrm{ab}$ & $10.22 \mathrm{ab}$ & 0.37 \\
\hline & 5 & $3.00 \mathrm{c}$ & $1.70 \mathrm{~cd}$ & $4.70 \mathrm{c}$ & 0.57 \\
\hline Glomus & 10 & $6.09 \mathrm{~b}$ & $2.20 \mathrm{bc}$ & $8.29 b$ & 0.36 \\
\hline versiforme & 8 & $3.14 \mathrm{c}$ & $1.50 \mathrm{cde}$ & $4.64 c$ & 0.48 \\
\hline
\end{tabular}

${ }^{\mathrm{a}}$ Within each column, means followed by the same letter are not significantly different by LSD at the $5 \%$ level.

root yields were displayed by plants colonized with $G$. mosseae and growing in $10 \mathrm{~cm}$ of soil overlying $5 \mathrm{~cm}$ of fly ash. There was a decreasing trend in yield with decreasing soil depth, and plants inoculated with G. mosseae had significantly lower yields in $5 \mathrm{~cm}$ of soil overlying $10 \mathrm{~cm}$ of fly ash compared with the deepest soil treatment. Inoculation with $G$. versiforme gave lower yields than with $G$. mosseae at the two soil/fly ash combinations in which the two fungi were compared. There were no consistent differences between mycorrhizal or substrate treatments in root/shoot ratio (Table 2).

\subsection{Shoot nutrient concentrations and offtakes}

Shoot concentrations of $\mathrm{P}$ and $\mathrm{K}$ were higher in mycorrhizal plants than in non-mycorrhizal controls (Table 3). Soil depth had no effect in non-mycorrhizal plants, but decreasing soil depth led to lower shoot concentrations of $\mathrm{P}$ and $\mathrm{K}$ in mycorrhizal plants. Mycorrhizal colonization had little effect on shoot $\mathrm{Mg}$ concentrations, but tended to lower shoot $\mathrm{Ca}$ and $\mathrm{Na}$ concentrations. Shoot concentrations of $\mathrm{Zn}$ and $\mathrm{Cu}$ were little affected by AM colonization, which tended to decrease shoot Mn.

Table 3 shows that shoot offtakes of all the elements studied except $\mathrm{Na}$ were higher in mycorrhizal maize than non-mycorrhizal controls, with higher offtakes in plants colonized by $G$. mosseae compared with $G$. versiforme. These trends are to be expected from the relatively large effects of AM colonization on shoot yield (Table 2). Nutrient offtakes were lower as soil depth decreased (Table 3).

\subsection{Root nutrient concentrations and offtakes}

In general, root nutrient concentrations followed similar trends to shoot concentrations, but with smaller 


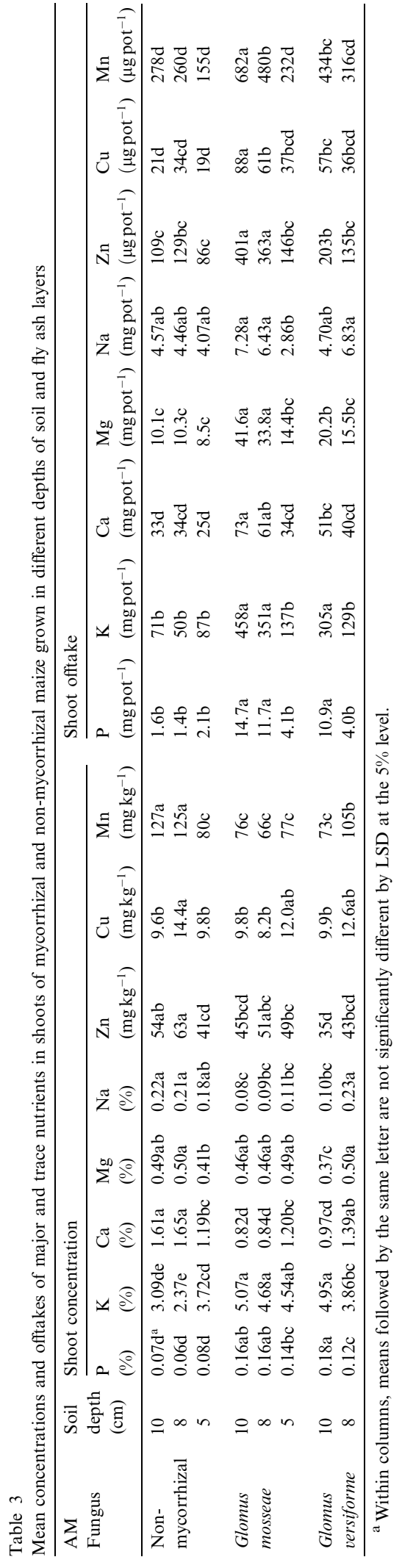

differences between treatments (Table 4). One exception was $\mathrm{Mg}$, with higher root concentrations in plants inoculated with G. mosseae. Root Na also showed opposite trends compared with shoot $\mathrm{Na}$, with higher root concentrations in plants colonized by G. mosseae.

Root offtakes of the elements were higher in mycorrhizal plants, especially those colonized by G. mosseae, and offtakes decreased with decreasing soil depth. Again, this was largely an effect on root yields, with offtakes particularly low in the lowest soil depth $(5 \mathrm{~cm})$ in plants colonized by $G$. mosseae.

\subsection{Total plant nutrient offtakes}

Table 5 shows the total plant offtakes of the elements studied. Offtakes by mycorrhizal plants were much higher than those by non-mycorrhizal controls, reflecting the yield effects of inoculation. Soil depth had little effect in non-mycorrhizal plants. Decreasing soil depth was associated with decreasing nutrient offtakes in mycorrhizal plants, especially those colonized by G. mosseae, the AM fungus that produced the more pronounced mycorrhizal plant growth effects.

\section{Discussion}

The results indicate that root colonization by both AM fungi gave higher maize yields, higher plant uptake of most of the nutrients studied, and may have protected the plants from excessive accumulation of $\mathrm{Na}$ in the shoots when grown in soil overlying fly ash. The effect of mycorrhizal colonization on the distribution of $\mathrm{Na}$ between roots and shoots was very striking. This may have been due to interaction with the increased $\mathrm{K}$ absorption by mycorrhizal plants, but this interpretation would require further studies for verification. It is interesting to compare the shoot nutrient concentrations (Table 3) with the critical leaf concentrations at the tasseling stage of maize reported by Hoeft and Peck (1991). Although the mycorrhizal plants had shoot P concentrations slightly below the critical level $(0.25 \%)$, they had about twice the concentrations of nonmycorrhizal controls. Concentrations of other nutrients examined were always higher than the critical levels. G. mosseae generally enhanced plant growth more than G. versiforme, indicating that different AM fungal species have different mycorrhizal effectiveness. The use of relatively undisturbed topsoil will introduce a suite of indigenous AM fungi, but more degraded materials will need to be inoculated with an effective fungal strain or a mixture of fungal strains. We do not know the proportion of the extra nutrients absorbed by mycorrhizal plants that were taken up from the fly ash rather than the soil. The roots had penetrated the fly 


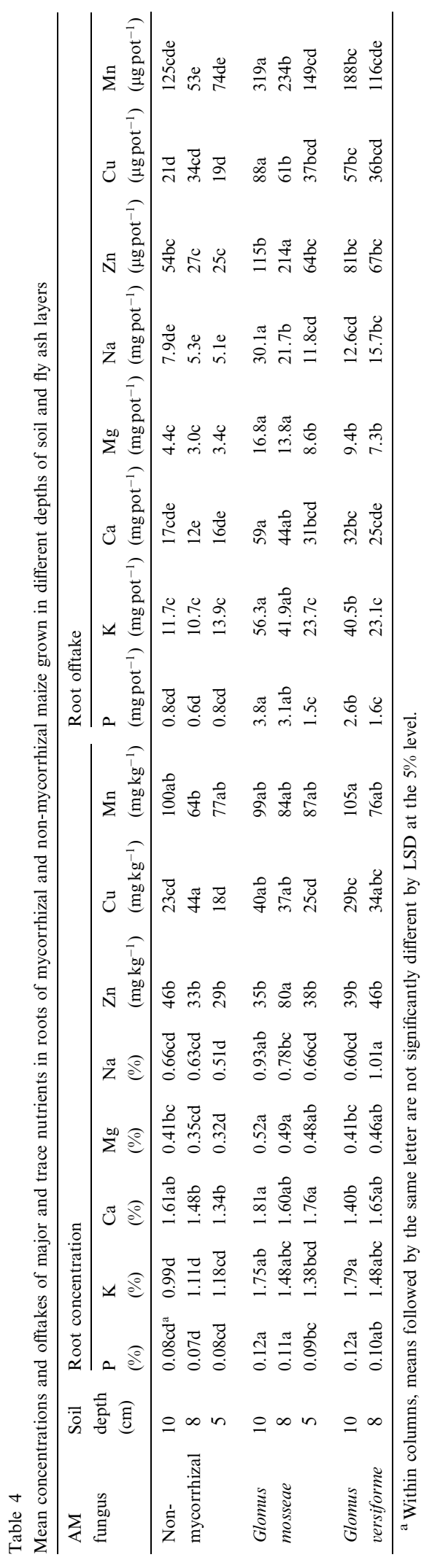

ash in all treatments, but further work is required to differentiate between uptake from the soil and from the fly ash.

Our data indicate that the maximum soil depth studied $(10 \mathrm{~cm})$ is required for satisfactory plant growth under the conditions of the experiment. However, greater depths may be advisable and further work is required to determine the optimum soil depth under field conditions. Long-term studies on perennial vegetation introduced on topsoil of depths 30,60, and $90 \mathrm{~cm}$ overlying retorted oil shale in Colorado showed that total above ground biomass was greatest on deeper topsoils (Sydnor and Redente, 2000). Although transportation of topsoil is expensive, the remediated areas will require substantial annual inputs of fertilizers to maintain agricultural productivity, and the cost of applying extra soil may be cost-effective in the long term.

Land clearing methods that remove mycorrhiza-rich surface soil and expose the subsoil, or that result in the death of mycorrhizal fungi in surface soil, can be expected to lower mycorrhizal inoculum potential (MIP) or to eliminate inoculum potential entirely (Alexander, 1989; Michelsen, 1992). In our experiment, inoculation with the two mycorrhizal fungi resulted in substantial root colonization (Table 1). Soil microorganisms are important components in re-vegetation of disturbed and potentially toxic environments because they can contribute to nutrient availability, immobilize heavy metals in the soil, and bind soil particles into stable aggregates that improve soil structure and reduce erosion potential. The majority of fine roots (Janos, 1984) and mycorrhizas (Rose and Paranka, 1987) in lowland, humid tropical forests occurred within the top $10 \mathrm{~cm}$ depth of the mineral soil. Mycorrhizal fungi are obligately aerobic (Harley and Smith, 1983), and so are unlikely to function far below the surface, unless deep plant roots are in proximity to large channels open to the surface such as those excavated by "leaf-cutter" ants (Atta spp.). Spores may be leached down through the soil profile by water or be carried by arthropods and other invertebrates, and so can be found deep in the soil, but their numbers are usually very low below 50-60 $\mathrm{cm}$ depth (Sieverding, 1991). Thus, soil cover quality is very important in soil re-vegetation. The absence of plant cover itself can result in reduced microbial populations and activity. Clearly, potentially beneficial rhizosphere microorganisms can be lost from mine spoils. The re-vegetation process may be complex, requiring a combined plant/microbe treatment for successful re-vegetation.

Rehabilitation of sites in which mycorrhizal function has been diminished may require both the quantitative and qualitative re-establishment of mycorrhizal fungal populations. That is, not only may MIP need to be enhanced, as in sites from which inocula have been substantially lost, but also mycorrhizal fungi may have to be 
Table 5

Mean total (root + shoot) offtakes of major and trace nutrients in mycorrhizal and non-mycorrhizal maize grown in different depths of soil and fly ash layers

\begin{tabular}{|c|c|c|c|c|c|c|c|c|c|}
\hline \multirow[t]{2}{*}{ AM fungus } & \multirow{2}{*}{$\begin{array}{l}\text { Soil } \\
\text { depth } \\
(\mathrm{cm})\end{array}$} & \multicolumn{8}{|c|}{ Total offtake } \\
\hline & & $\begin{array}{l}\mathrm{P} \\
\left(\mathrm{mg} \mathrm{pot}^{-1}\right)\end{array}$ & $\begin{array}{l}\mathrm{K} \\
\left(\mathrm{mg} \mathrm{pot}^{-1}\right)\end{array}$ & $\begin{array}{l}\mathrm{Ca} \\
\left(\mathrm{mg} \mathrm{pot}^{-1}\right)\end{array}$ & $\begin{array}{l}\mathrm{Mg} \\
\left(\mathrm{mg} \mathrm{pot}^{-1}\right)\end{array}$ & $\begin{array}{l}\mathrm{Na} \\
\left(\mathrm{mg} \mathrm{pot}^{-1}\right)\end{array}$ & $\begin{array}{l}\mathrm{Zn} \\
\left(\mu \mathrm{g} \mathrm{pot}^{-1}\right)\end{array}$ & $\begin{array}{l}\mathrm{Cu} \\
\left(\mu \mathrm{g} \mathrm{pot}^{-1}\right)\end{array}$ & $\begin{array}{l}\mathrm{Mn} \\
\left(\mu \mathrm{g} \mathrm{pot}^{-1}\right)\end{array}$ \\
\hline \multirow[t]{3}{*}{ Non-mycorrhizal } & 10 & $2.5 \mathrm{c}^{\mathrm{a}}$ & $83 \mathrm{c}$ & $50 \mathrm{~d}$ & $14.5 \mathrm{~cd}$ & $12.5 \mathrm{~d}$ & $164 b c$ & $47 \mathrm{ef}$ & 403de \\
\hline & 8 & $1.9 \mathrm{c}$ & $61 \mathrm{c}$ & $47 d$ & $13.3 \mathrm{~cd}$ & $9.8 \mathrm{~d}$ & $156 \mathrm{c}$ & $65 \mathrm{def}$ & $313 \mathrm{de}$ \\
\hline & 5 & $2.9 \mathrm{c}$ & $102 \mathrm{c}$ & $42 d$ & $11.8 \mathrm{~d}$ & $9.5 \mathrm{~d}$ & $107 \mathrm{c}$ & $35 f$ & $227 \mathrm{e}$ \\
\hline \multirow[t]{3}{*}{ Glomus mosseae } & 10 & $18.5 \mathrm{a}$ & $514 \mathrm{a}$ & $132 \mathrm{a}$ & $58.4 \mathrm{a}$ & $37.4 \mathrm{a}$ & $516 \mathrm{a}$ & $216 \mathrm{a}$ & $1001 \mathrm{a}$ \\
\hline & 8 & $14.9 \mathrm{ab}$ & $393 \mathrm{ab}$ & $105 \mathrm{ab}$ & $47.7 \mathrm{a}$ & $28.1 \mathrm{~b}$ & $577 \mathrm{a}$ & $164 b$ & $714 b$ \\
\hline & 5 & $5.6 \mathrm{c}$ & $161 \mathrm{c}$ & $65 \mathrm{~cd}$ & $23.0 \mathrm{bc}$ & $14.6 \mathrm{~d}$ & $211 b c$ & $79 \mathrm{cde}$ & $381 \mathrm{de}$ \\
\hline \multirow[t]{2}{*}{ Glomus versiforme } & 10 & $13.6 \mathrm{~b}$ & $346 b$ & $83 \mathrm{bc}$ & $29.6 b$ & $17.3 \mathrm{~cd}$ & $285 b$ & $120 \mathrm{c}$ & $622 b c$ \\
\hline & 8 & $5.6 \mathrm{c}$ & $152 \mathrm{c}$ & $65 \mathrm{~cd}$ & $22.8 \mathrm{bcd}$ & $22.5 b c$ & $202 b c$ & $91 \mathrm{~cd}$ & $432 \mathrm{~cd}$ \\
\hline
\end{tabular}

${ }^{\mathrm{a}}$ Within columns, means followed by the same letter are not significantly different by LSD at the $5 \%$ level.

replaced to restore a diverse fungal community. Although extreme land degradation may eliminate mycorrhizal fungi from entire sites, leading to highly depauperate vegetation, patchy mycorrhiza formation that limits establishment of only some seedlings is more common than the extreme.

Fly ash is composed of predominantly silt-sized, spherical, amorphous ferro-aluminosilicate minerals (Carlson and Adriano, 1993). Approximately 10\% of that produced in the US is sold to the cement industry and the rest is buried in disposal sites or lagooned. Fly ash can supply essential elements to crops growing on nutrient-deficient soils, and highly alkaline fly ashes are potential liming agents. Fly ash amendments have corrected plant nutritional deficiencies of $\mathrm{B}$ (Ransome and Dowdy, 1987), Mg (Hill and Lamp, 1980), Mo (Elseewi et al., 1980), S (Elseewi et al., 1980; Hill and Lamp, 1980) and Zn (Martens, 1971; Schnappinger et al., 1975). Boron phytotoxicity is probably the greatest potential problem to crops associated with high application rates of certain unweathered fly ashes to soil (Carlson and Adriano, 1993). In our experiment we found no symptoms of B toxicity. The plants may have taken up $\mathrm{K}, \mathrm{Mn}, \mathrm{Fe}$, and $\mathrm{Ca}$ derived from the fly ash. Thus, the combination of a surface soil layer and a layer of fly ash underneath can provide a substrate capable of supporting plant growth.

Shoot $\mathrm{P}$ concentrations have often been lowered by fly ash applications (Elseewi et al., 1980; Moliner and Street, 1982). In our experiment, however, the plants could absorb $\mathrm{P}$ directly from the soil, and the external hyphae of the mycorrhizal fungi also contributed to $\mathrm{P}$ uptake from the substrate, possibly including the fly ash. The liming effect of the fly ash and the formation of insoluble complexes (Gray and Schwab, 1993) may have hampered uptake of P. AM hyphae can lower the $\mathrm{pH}$ of rhizosphere soil, leading to an increase in plant uptake of soil P (Li et al., 1991). Plant availability of fly ash K has also been reported to be low, despite high total concentrations in the fly ash (Martens et al., 1970). In our experiment, inoculation with the mycorrhizal fungi led to an increase in $\mathrm{K}$ uptake from soil, and possibly from the fly ash.

The establishment of mycorrhizas in mine spoil amended with fly ash may require the addition of AM fungal strains more suited for such an environment. Selection, culture and inoculation of soil organisms highly adapted to the types of plants and soil conditions of a severely disturbed landscape may be an effective means for ensuring success of the re-vegetation effort.

\section{Conclusions}

This preliminary pot study indicates that successful growth of maize is possible in soil overlying coal fly ash and can be improved by colonization of the plant roots by mycorrhizal fungi. Thus, remediation of areas infilled with coal fly ash may be possible using either undisturbed soil containing viable propagules of indigenous AM fungi or disturbed soil inoculated with effective strains of AM fungi. The fungi can assist plants in the exploitation of soil (and possibly fly ash) nutrients and may help them to resist excessive salt $(\mathrm{Na})$ accumulation in the shoots. AM fungi may also contribute to the re-establishment of a general soil microflora, and of a sustainable agricultural system combined with the appropriate use of fertilizers. Further studies are required to determine the optimum depth of soil required. Long-term field studies will help to define the inputs and conditions necessary for successful annual crop production. 


\section{Acknowledgements}

This work was funded by the Major State Basic Research Development Programme of the People's Republic of China (Project G1999011807) and the National Natural Science Foundation of China (Project 40071050). We thank Dr David J. Kilpatrick of the Biometrics Department, Queen's University Belfast, for the statistical analysis of the data.

\section{References}

Alexander, I., 1989. Mycorrhizas in tropical forests. In: Proctor, J. (Ed.), Mineral Nutrients in Tropical Forest and Savanna Ecosystems. Blackwell, Oxford, pp. 169-188.

Carlson, C.L., Adriano, D.C., 1993. Environmental impacts of coal combustion residues. J. Environ. Qual. 22, 227-247.

Cook, B.D., Jastrow, J.D., Miller, R.M., 1988. Root and mycorrhizal endophyte development in a chronosequence of restored tallgrass prairie. New Phytol. 110, 355-362.

Elseewi, A.A., Straughan, I.R., Page, A.L., 1980. Sequential cropping of fly ash-amended soils: Effects on soil chemical properties and yield and elemental composition of plants. Sci. Total Environ. 15, 247-259.

GENSTAT Committee, 1994. GENSTAT 5 reference manual. Clarendon Press, Oxford.

Gray, C.A., Schwab, A.P., 1993. Phosphorus-fixing ability of high $\mathrm{pH}$, high calcium, coal combustion waste materials. Water Air Soil Pollut. 69, 309-320.

Harley, J.L., Smith, S.E., 1983. Mycorrhizal Symbiosis. Academic Press, New York.

Hetrick, B.A.D., Wilson, G.W.T., Figge, D.A.H., 1994. The influence of mycorrhizal symbiosis and fertilizer amendments on establishment of vegetation in heavy metal mine spoil. Environ. Pollut. 86, 171-179.

Hill, M.J., Lamp, C.A., 1980. Use of pulverised fuel ash from Victorian brown coal as a source of nutrients for a pasture species. Aust. J. Exp. Agric. Anim. Husb. 20, 377-384.

Hoeft, R.G., Peck, T.R., 1991. Soil testing and fertility. In: Illinois Agronomy Handbook. Circular 1311. University of Illinois, Urbana-Champaign, IL.

Janos, D.P., 1984. Methods for vesicular-arbuscular mycorrhiza research in the lowland wet tropics. In: Medina, E., Mooney, H.A., Vazquez-Yanes, C. (Eds.), Physiological Ecology of Plants in the Wet Tropics. Dr W. Junk, The Hague, pp. 173-187.

Li, X.L., George, E., Marschner, H., 1991. Phosphorus depletion and $\mathrm{pH}$ decrease at the root-soil and hyphaesoil interfaces of VA mycorrhizal white clover fertilized with ammonium. New Phytol. 119, 397-404.

Lindermann, R.G., 1988. Mycorrhizal interaction with the rhizosphere microflora: The mycorrhizosphere effect. Phytopathology 78, 366-371.

Martens, D.C., 1971. Availability of plant nutrients in fly ash. Compost. Sci. 12, 15-19.

Martens, D.C., Schnappinger Jr., M.G., Zelazny, L.W., 1970. The plant availability of potassium in fly ash. Soil Sci. Soc. Am. Proc. 34, 453-456.
Michelsen, A., 1992. Mycorrhiza and root nodulation in tree seedlings from five nurseries in Ethiopia and Somalia. For. Ecol. Manage. 48, 335-344.

Moliner, A.M., Street, J.J., 1982. Effect of fly ash and lime on growth and composition of corn (Zea mays L.) on acid sandy soils. Proc. Soil Crop Sci. Soc. Fla. 41, 217220.

Noyd, R.K., Pfleger, F.L., Russelle, M.P., 1995. Interactions between native prairie grasses and indigenous arbuscular mycorrhizal fungi: Implications for reclamation of taconite iron ore tailing. New Phytol. 129, 651-660.

Perry, D.A., Amaranthus, M.P., 1990. The plant-soil bootstrap: Microorganisms and reclamation of degraded ecosystems. In: Berger, J.J. (Ed.), Environmental Restoration: Science and Strategies for Restoring the Earth. Island Press, Washington, DC, pp. 94-102.

Phillips, J.M., Hayman, D.S., 1970. Improved procedures for clearing roots and staining parasitic and VA mycorrhizal fungi for rapid assessment of infection. Trans. Br. Mycol. Soc. $55,158-160$.

Pichtel, J.R., Dick, W.A., Sutton, P., 1994. Comparison of amendments and management practices for long-term reclamation of abandoned mine lands. J. Environ. Qual. 23, 766-772.

Ransome, L.S., Dowdy, R.H., 1987. Soybean growth and boron distribution in a sandy soil amended with scrubber sludge. J. Environ. Qual. 16, 171-175.

Reddell, P., Milnes, A.R., 1992. Mycorrhizas and other specialized nutrient-acquisition strategies: Their occurrence in woodland plants from Kakadu and their role in rehabilitation of waste rock dumps at a local uranium mine. Aust. J. Bot. 40, 223-242.

Rose, S.L., Paranka, J.E., 1987. Root and VAM distribution in tropical agricultural and forest soils. In: Sylvia, D.M., Hung, L.L., Graham, J.H. (Eds.), Mycorrhizae in the Next Decade. Institute of Food and Agricultural Sciences, Gainesville, FL, p. 56.

Sabey, B.R., Pendleton, R.L., Webb, B.L., 1990. Effect of municipal sewage sludge application on growth of two reclamation shrub species in copper mine spoils. J. Environ. Qual. 19, 580-586.

Schnappinger Jr., M.G., Martens, D.C., Plank, C.O., 1975. Zinc availability as influenced by application of fly ash to soil. Environ. Sci. Technol. 9, 258-261.

Schumann, A.W., Sumner, M.E., 1999. Plant nutrient availability from mixtures of fly ashes and biosolids. J. Environ. Qual. 28, 1651-1657.

Sieverding, E., 1991. Vesicular-arbuscular Mycorrhiza Management in Tropical Agroecosystems. Deutsche Gesellschaft fur technische Zusammenarbeit (GTZ) gmbh, Eschborn.

Sydnor, R.S., Redente, E.F., 2000. Long-term plant community development on topsoil treatments overlying a phytotoxic growth medium. J. Environ. Qual. 29, 17781786.

Thorne, M.E., Zamora, B.A., Kennedy, A.C., 1998. Sewage sludge and mycorrhizal effects on secar bluebunch wheatgrass in mine spoil. J. Environ. Qual. 27, 1228-1233.

Wong, J.W.C., 1995. The production of artificial soil mix from coal fly ash and sewage sludge. Environ. Technol. 16, 741751. 